\title{
Today, Tomorrow, and the Future of Energy Storage Materials for Solar Energy
}

\author{
Dawar Ali ${ }^{1}$, Mehmet Fatih Kaya ${ }^{2 *}$, Levent Şendoğdular ${ }^{3}$
}

\begin{abstract}
Increasing global energy demand and environmental concerns due to the emissions of greenhouse gases as by-products of fossil fuel consumption have led to the exploration of the potential of renewable energy sources such as solar, biofuel, hydrothermal energy etc. Among these, solar thermal energy is becoming a highly desirable source of renewable energy because of the widespread availability of solar radiations and the progress achieved in its efficiency and effectiveness.

Different forms of thermal storage especially thermochemical storage (TCS), latent heat storage (LHS), and sensible heat storage (SHS) have been reported so far. Likewise, there are studies in the literature which also focus on the main mechanical energy storage systems. In addition, electrochemical energy storage devices like batteries are increasingly gaining popularity due to their highly efficient energy conversion values. Recently investigated materials for various solar storage forms show great potential as the future storage materials since theoretical limits are not reached yet; however, they are still in the experimental stage and this paper presents glimpse of those potential studies.
\end{abstract}

Keywords: Solar energy, storage materials, batteries, thermal energy

\section{Güneş Enerjisi Depolama Malzemelerinin Bugünü, Yarını ve Geleceği}

\section{Öz}

Fosil yakıtların tükenmeye başlaması ve bu yakıtların yan ürünleri olarak ortaya çıkan sera gazı salınımları, bunun yanı sıra artan küresel enerji talebi ve çevresel endişeler, güneş, biyoyakıt, hidrotermal enerji gibi yenilenebilir enerji kaynaklarının potansiyelinin daha da detaylı araştırılmasına yol açmıştır. Bunlar arasında termal güneş enerjisi sistemleri yenilenebilir enerji sistemleri içerisinde güneş 1şığına kolay erişilebilir olması, elde edilen verimlilik değerleri ve etkili bir enerji dönüşümü sağlanması sebebiyle çok yaygın olarak tercih edilen sistemler haline gelmiştir. Şimdiye kadar farklı termal depolama biçimleri, özellikle termokimyasal depolama (TCS), artık 1sıl depolama (LHS) ve hissedilir 1sı depolaması (SHS) ilgili kapsamlı çalışmalar yapılmıştır. Bunların yanı sıra literatürde de ana enerji depolama sistemleri olarak mekanik enerji depolama sistemlerine de odaklanan çalışmalar bulunmaktadır. Ek olarak, bataryalar gibi elektrokimyasal enerji depolama sistemleri yüksek enerji dönüşüm verimleri sayesinde giderek daha fazla popülerlik kazanmaktadır. Çeşitli güneş depolama yöntemleri için yakın zamanda araştırılan malzemeler, teorik sınırlara henüz ulaşılmadığ1 için güneş enerjisi depolama malzemeleri konusu araştırmacılar için büyük bir potansiyel göstermektedir. Ancak bu çalışmaların çoğu halen deneysel aşamada olup bu değerlendirme çalışmasında güneş enerjisi depolaması ile ilgili malzeme temelli bu potansiyel çalışmalara bir bakış açısı sunulması sağlanmıştır.

Anahtar Kelimeler: Güneş Enerjisi, depolama malzemeleri, bataryalar, termal enerji.

\footnotetext{
" İletișim Yazarı

Geliș/Received

21.09.2020

Kabul/Accepted

21.10 .2020

1 Erciyes Üniversitesi, Mühendislik Fakültesi, Malzeme Bilimi ve Mühendisliği, Melikgazi, Kayseri dawar1424@gmail.com, ORCID:0000-0002-1432-5557

2 Erciyes Üniversitesi, Mühendislik Fakültesi, Enerji Sistemleri Mühendisliği, Melikgazi, Kayseri kayamehmetfatih@erciyes.edu.tr, ORCID: 0000-0002-2444-0583

3 Erciyes Üniversitesi, Mühendislik Fakültesi, Malzeme Bilimi ve Mühendisliği, Melikgazi, Kayseri lsendogdular@erciyes.edu.tr, ORCID: 0000-0002-6364-0932
} 


\section{INTRODUCTION}

In this era, energy shortage and environmental issues need to be addressed urgently and globally [1-3]. As compared to 2017, the energy consumption in 2018 increased $1.5 \%$ worldwide [4]. A statistical study by British Petroleum shows that global energy demand is continously increasing and fossil fuel share has almost reached to $87 \%$ of the total consumption [1]. Nuclear energy causes less greenhouse emissions and therefore seems to be a promising candidate in terms of environmentally friendly energy source, but it has security problems based on infrastructure and is also very expensive to maintain [3]. Greenhouse gas emissions can only be reduced or at least avoided by consuming renewable energy and therefore, many countries have taken initiatives in this regard [5-11].

Although renewable energy sources cannot be adopted widely because of geographical limitations, economic and atmospheric conditions; they have low environmental damage, produce almost insignificant pollution, and their derivatives are widely available. Among the many other renewable energy sources like wind, biogas, hydrothermal etc., Sun is the major source of clean energy worldwide. Solar energy can be converted to electrical power by both concentrated solar power (CSP) systems and photovoltaics (PVs) [4, 12]. PV cells usually convert solar energy to chemical energy which can be stored in batteries and can be converted into electrical current when needed while CSP systems help to store solar energy as heat to be used as electricity after all [13].

The fundamental parts of any solar thermal system are those which store and collect energy. Solar collectors either transform solar energy into electrical energy using PV methods or into thermal energy of a storage material $[14,15]$. PV, solar thermal, and PV/T (photovoltaic/thermal) are the three main solar collectors [6]. PV technology gained massive interest in the last decade in the form of both domestic and remote installations [16] whereas the solar thermal technology has relatively been employed in the housing sector for around half a century now [10]. Thermal energy is further categorized as latent heat, sensible heat and thermochemical heat storage.

Latent heat storage or phase change materials in other words although has low thermal conductivity [7], is considered better than sensible storage due to its high storage density and limited phase transition range [17]. Latent and sensible heat storage do not have the potential to store energy for longer periods of time like from one season to another, instead they can only store energy for a few hours. Therefore, TCS is viable as it solves the issue of longer period energy storage [8]. In this review, the main energy storage materials, or systems like thermal, mechanical, and electrical are considered. Moreover, the potential future storage materials are also presented briefly. 


\section{THERMAL STORAGE MATERIALS}

The flow chart in Figure 1 summarizes the main types of energy storage systems used for solar radiation. Among these thermal, mechanical and electrochemical storage are mainly and widely used systems. Based on the storage mechanism, TES materials can be simply divided into sensible (SHS), thermochemical (TCS), and latent heat storage (LHS) materials [19].

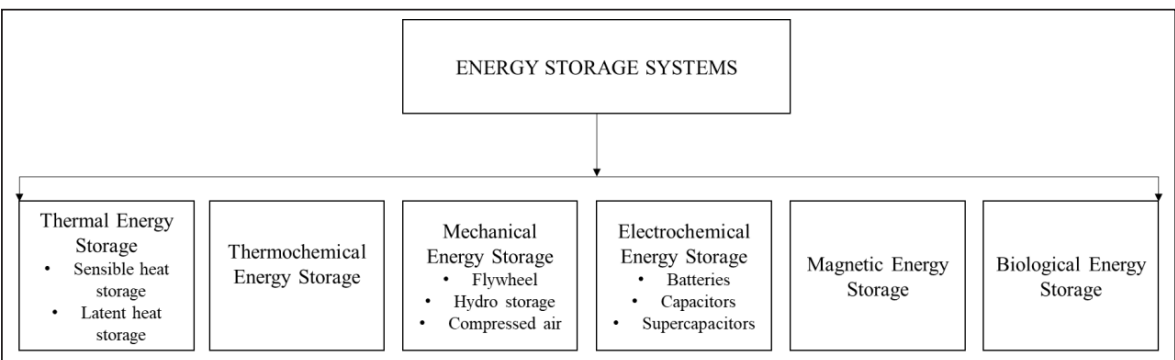

Figure 1. Classification of Energy Storage Systems [18].

\subsection{Sensible Heat Storage}

The SHS materials do not have to go through a phase change process to store the thermal energy. The extent of thermal energy stored depends on the thermophysical characteristics of the storage material and can be expressed in the form of relationship (1):

$Q=m \cdot C p \cdot \Delta T=m \cdot C p \cdot\left(\mathrm{T}_{2}-\mathrm{T}_{1}\right)$

Where $\mathrm{Q}$ is the thermal energy as sensible heat, $\mathrm{m}$ is the mass of the storage material in $\mathrm{kg}, C p$ is the specific heat capacity in $\mathrm{kJ} / \mathrm{kg} . \mathrm{K}$; and $\mathrm{T}_{1}$ and $\mathrm{T}_{2}$ are the initial and final temperatures in $\mathrm{K}$ [20]. The materials for sensible heat storage can be solids or fluids.

\subsubsection{Liquid Storage}

Also called as an active system, a liquid storage material can easily circulate and transport the heat. Such kind of system is named as active system. Another major advantage of liquids is that they create a thermal gradient between the hot and the cold fluid. As a result, the density of the storage fluid changes causing the hotter part of the fluid to rise up naturally [21].

\subsubsection{Water}

With a working temperature range between $25-90{ }^{\circ} \mathrm{C}$ for low temperature applications, water is the best storage material in this range [22]. The best usage of water is in the form of hot water supply as in residential heating. Materials like aluminium, steel, fiberglass, and reinforced concrete are used for water tanks and heat insulated with polyurethane, wool, or mineral wool. 
Hot water mixed with sand gravels in underground can serve as a seasonal large-scale facility for energy storage. This kind of system significantly reduces the water tank construction costs [23].

\subsubsection{Mineral Oil}

Mineral oil is mostly chosen as cooling or heating fluid in the concentrated solar power plants passing through the receiver, collecting heat, and providing it to the boiler for the production of steam for turbine [24]. Mineral oil is less volatile than water and can bear temperatures up to $400{ }^{\circ} \mathrm{C}$ without evaporating, allowing it to operate at higher temperatures. The only condition affecting their performance is that they degrade with time and beyond a certain limiting temperature [25].

\subsubsection{Molten Salts}

Molten salts are cheaper, have higher energy storage density and a reduced vapor pressure as compared to water enabling them to work up to $400{ }^{\circ} \mathrm{C}$. For those reasons, they are in high demand in CSP plants as thermal energy storage materials [26]. The most commonly used molten salts remain in the liquid phase throughout the operation even at nights without the need of an antifreeze. Salt composites are used to keep the liquid between $100-500{ }^{\circ} \mathrm{C}$ [26]. In addition, Zhao and $\mathrm{Wu}$ [19] reported a variety of ternary salt mixtures with melting temperatures less than $100{ }^{\circ} \mathrm{C}$. Those $\mathrm{LiNO}_{3}, \mathrm{Ca}$ $\left(\mathrm{NO}_{3}\right) 2$, and $\mathrm{KNO}_{3}$ mixtures can operate around $500{ }^{\circ} \mathrm{C}$ with viscosities $80 \%$ lower than their commercial counteracts. Moreover, they are corrosive at higher temperatures since they have an oxidizing nature [27].

\subsubsection{Molten Metals and Alloys}

Metals and alloys in the pure form have a higher thermal conductivity, low vapor pressure, higher maximum operating temperature. Therefore, metals and alloys with melting points above $300{ }^{\circ} \mathrm{C}$ can be used as a storage media for sensible heat. In the literature $\mathrm{Zn} / \mathrm{Mg}$ (53.7/46.3), $\mathrm{Zn} / \mathrm{Al}$ (96/4), $\mathrm{Al} / \mathrm{Cu} / \mathrm{Si} / \mathrm{Mg}(64.6 / 28 / 5.2 / 2.2), \mathrm{Mg} / \mathrm{Ca}$ (84/16), Si/Al (86/12) can be used commonly as molten metals and their alloys [28]. However, they are also corrosive [22].

\subsubsection{Solid Storage Medium}

Solid materials like rocks, bricks, concrete, sand, and metals can be used for all types of energy storage since they do not boil and freeze. They do not have limitations of liquids, but they have a limitation of circulation as well. Therefore, they can be utilized for passive storage only where air normally transfers the heat. Thus, they are better for applications that need low temperature like space heating and recovery of industrial waste heat. Among all the solid materials pebbles and rock piles are the most preferred since they are cheaper [22]. 


\subsubsection{Rocks}

Rocks around $5 \mathrm{~cm}$ are used together with air or a mineral oil which serve as heat transfer fluids in sand-rock-mineral combinations. In the rock heat storage, heated air passes through the holes between rocks charging them, in the same way cold air circulates through the rocks and gets heated. Rocks are easily available, cheap, nonflammable, and non-toxic, whereas they also face the issues like reduced pressure drops and low air mass flow rates [29]. As an example, appropriate amount is around $300-500 \mathrm{~kg}$ rock $/ \mathrm{m}^{2}$ for thermal energy storage required in space heating.

\subsubsection{Concrete}

Because of its high mechanical strength, the concrete is easily applicable as an SHS material and hence, a container is not required. By circulating the heat transfer fluid (HTF) through the pipes fixed inside a concrete block, heat exchange between concrete and an HTF can occur. In high-temperature applications, its probability to crack under repeated thermal contraction and expansion cycles might be a drawback but research is underway to establish the best suited mixing method to improve chemical-physical characteristics and durability at elevated temperatures [30]. Practical applications have proved that $400 \mathrm{kWh}$ of energy can be stored in $20 \mathrm{~m} 3$ of concrete.

\subsubsection{Sand}

Thermal energy can easily be stored in the fine grained gravel and silica sand. Air as an HTF can perform heat transfer within sand grain beds with $0.2-0.5 \mathrm{~mm}$ diameter. Those beds have been measured up to a storage capacity of $550{ }^{\circ} \mathrm{C}$ [31]. The packing density is determined by the fineness of the sand. Finer sand has a greater density of packing. Gravels have grains of $0.4 \mathrm{~mm}$. diameter. To use as solar thermal energy storage options, basalt gravels can be used directly for the solar systems. The gravels fall under gravity absorbing solar energy in the receiver. The Rankine cycle power plant is driven by the steam which is produced by the sand at $700-1000{ }^{\circ} \mathrm{C}$ at the bottom of the receiver.

\subsubsection{Bricks}

To reduce the space heating electricity cost, building wall bricks can store thermal energy [22]. During the off-peak hours at night, bricks are heated and store heat. During the day, the heat is extracted by convection or radiation. During the peak hours the stored heat is utilized to keep the buildings warm and this saves the cost of electricity [32].

\subsection{Thermochemical Heat Storage}

In the thermochemical heat storage systems, reversible chemical reaction is employed to store solar-thermal energy [33]. The heat energy stored equals the enthalpy of the reaction. The storage process occurs with the conversion of reactant (A) to products 
(B and $\mathrm{C}$ ) at the end of the reaction. The backward reaction (exothermic) also generates the $\mathrm{A}$ and releases stored heat during the chemical discharge process. Both endothermic and exothermic reaction products can be stored at ambient or working temperatures. Thermal energy stored in thermochemical material can be calculated by:

$Q=n . H$

Where n represents the reactants' mol number (mol) and $\Delta H$ is the reaction enthalpy $\left(\mathrm{kJ} \mathrm{mol}^{-1}\right)$. Unfortunately, thermochemical energy storage studies are still in laboratory scale, but sensible and latent heat storage studies are in the industrial level. Thermochemical energy storage provides about 6 times the energy density of latent heat storage and 15 times that of sensible heat storage [8, 34]. Thus, this proves how efficient this system can be compared to others.

\subsection{Latent Heat Storage}

During the melting, phase change materials (PCM) are usually called as "latent fusion fuel". Phase change reaction occurs during the thermal energy absorption and the temperature fluctuation is very insignificant. Materials store thermal energy as the phase change with the equation below;

$Q=m \cdot H$

Here, mass $\mathrm{m}$ is in $\mathrm{kg}$ and the latent heat of fusion, $\mathrm{H}$ is in $\mathrm{kJ}^{\mathrm{kg}} \mathrm{kg}^{-1}$. Usually, phase change occurs between solid and liquid phases [28]. This method is very common

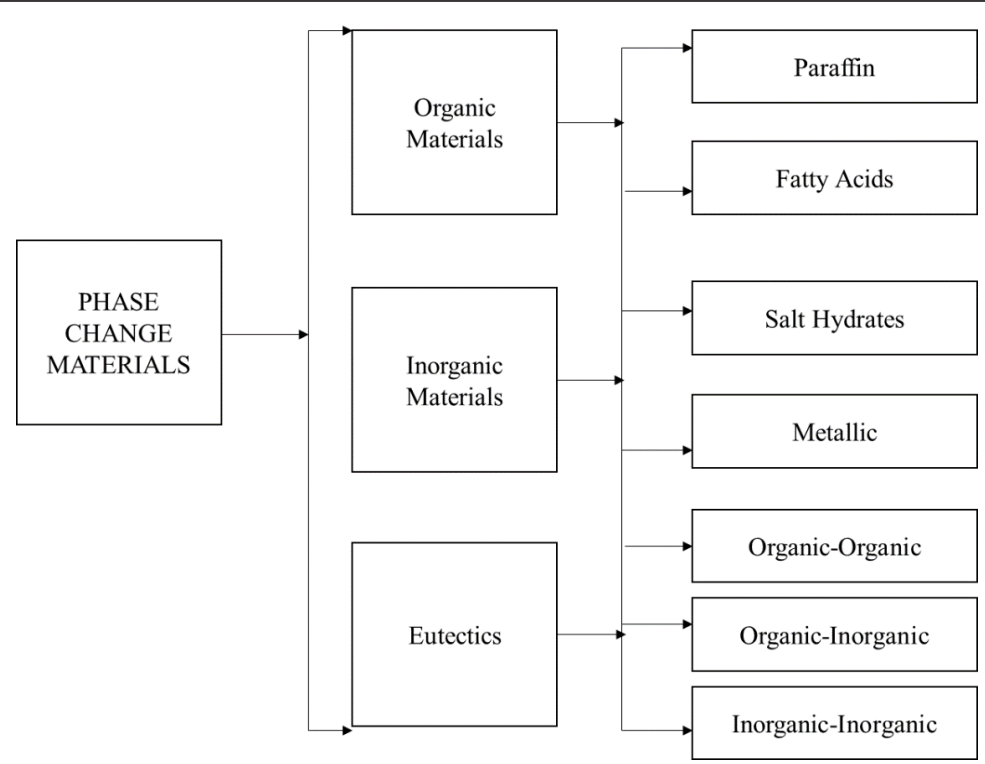

Figure 2. Classification of Phase Change Materials (PCMs) [35, 36] 
in industrial applications in the last ten years. The Figure 2 below presents the main types of phase change materials; organic, inorganic and eutectics which can be further categorized. All the PCMs are discussed in detail in the following sections.

\subsubsection{Organic Materials}

For many residential and commercial applications, $\mathrm{CHO}$ based latent heat materials (organics) and the mixtures of these organic based materials have proven to be successful and have been used in space heating applications for homes, air conditioning systems, electronic equipment, solar/water heating systems, food, automobiles, textiles, and space industries [12]. Organic PCMs have low melting temperatures restricting their use in power plants as they require high temperatures.

\subsubsection{Paraffin}

Paraffin waxes are members of n-alkanes group $\left(\mathrm{CH}_{3}-\left(\mathrm{CH}_{3}\right)-\mathrm{CH}_{3}\right)$ by their simple chains [37]. Due to the high cost of paraffin purity, professional quality paraffin waxes are used for these storage studies. Commercially used paraffin is the product of distillation of crude oil. Mostly, paraffins which have saturated carbon are more suitable for PCMs. They have different carbon atoms in their molecules. In these applications, the paraffin wax is used as the PCM and filled inside the tubes. The heat exchange takes place between paraffin and water through heat exchangers.

\subsubsection{Fatty acids, Esters, Alcohols and Glycols}

Fatty acids of $\left(\mathrm{CH}_{3}\left(\mathrm{CH}_{2}\right) 2 \mathrm{n}-\mathrm{COOH}\right)$ type are the perfect fit as low temperature latent heat storage materials with the best thermophysical properties. They are more expensive than paraffins of professional quality, slightly corrosive and have an unpleasant odour. They are naturally combustible [37].

Esters consist of one group of hydroxyls and alkyls. In the small temperature range, esters exhibit solid-liquid phase change [38].

Polyalcohol or sugar alcohol are called medium temperature PCMs suitable between $90{ }^{\circ} \mathrm{C}$ and $200{ }^{\circ} \mathrm{C}$. In the last 40 years, alcohols have been considered as potential PCMs. Although not much research has been done since then, some studies indicated that xylitol, mannitol, and erythritol have almost $300 \mathrm{~kJ} / \mathrm{kg}$ latent heat due to fusion reactions [39]. This potential has been recorded as the highest value up to which other alternative materials could not reach.

Polyethylene glycol (PEG) is known as polyoxyethylene (POE) and polyethylene oxide (PEO). PEG is located in hydroxyl group and it has dimethyl ether chains with a formula of $\mathrm{HO}-\mathrm{CH}_{2}-\left(\mathrm{CH}_{2}-\mathrm{O}-\mathrm{CH}_{2}-\right) \mathrm{n}-\mathrm{CH}_{2}-\mathrm{OH}$. It can dissolve in water and organic compounds. PEGs have also different grades such as PEG600, PEG400 etc. In literature, there exists some earlier studies focused on those materials [40]. They are chemically heat resistant, non-toxic, non-flammable, inexpensive, and non-corrosive. 
The PEGs' latent heat of fusion and melting point is directly proportional to the molecular weight [41]. Like other organic PCMs, PEG also has low thermal conductivity.

\subsubsection{Inorganic Materials}

Inorganic PCMs typically have a heat storage capacity twice that of organic materials per unit volume. The latent heat density is around $350 \mathrm{MJ} / \mathrm{m} 3$. They also exceed organic PCMs by having superior thermal conductivities, lower operating temperatures and costs [26]. They are corrosive, which ensures that the devices that contain them have shorter service lives, which raise their costs.

\subsubsection{Salt Hydrates}

Salt hydrates are usually used in the range of $30-50^{\circ} \mathrm{C}$ at low operating temperatures. They are denoted by a general formula of AB.nH2O. This can somehow be considered as the representation of water of crystallization of inorganic salt compounds. During the phase change, salt dehydrates and stores the energy. This could be either in the form of a salt with less water or an anhydrous salt [42].

\subsubsection{Salts}

Salts with lower melting temperatures store liquids as a sensible medium. Yet, they can store heat as high as $100^{\circ} \mathrm{C}$ for high temperature applications. They can be divided into many material types such as carbonates, nitrates, chlorides, and hydroxides, having a wide melting temperature range $[43,44]$

\subsubsection{Metals and Their Alloys}

It is well-known that metals have very good thermal conductivity and stability. Moreover, they have good mechanical strength and they can be used again and again for thermal storage without deteriorating their properties at high temperatures [38] Among all materials, metals exhibit the highest phase transfer heat per unit mass or unit volume. Hence, their energy storage potential is very high. Volume change after phase transition is also insignificant. The vapor pressure is also very low. However, they are competitors of salts when volume is important [28].

\subsubsection{Eutectic}

Eutectics have organic - inorganic, organic - organic, and inorganic - inorganic components. They change their phase in agreement with each other. Eutectics have fixed solidification and liquefaction temperatures. They transform crystal components during the crystallization reactions. Eutectics usually freeze and melt congruently and do not undergo separation.

Alnaimat et al. [45] studied the thermal energy storage systems for solar energy in detail. In Table 1, a summary of different energy storage systems can be seen. Different thermal energy storage systems based on different criteria are also compared in Table 
1. The heat losses are the lowest in thermo-chemical while the storage duration is the longest as compared to the other two systems. However, the easiest system to operate among those three is the sensible energy storage.

Table 1. Comparison of Different Energy Storage Systems [45]

\begin{tabular}{|c|c|c|c|}
\hline Criteria & $\begin{array}{l}\text { Sensible Energy } \\
\text { Storage System }\end{array}$ & $\begin{array}{l}\text { Latent Energy } \\
\text { Storage System }\end{array}$ & $\begin{array}{c}\text { Thermo-chemical Energy } \\
\text { Storage System }\end{array}$ \\
\hline Operation & Easy & Medium & Hard \\
\hline Density & Too low & Medium & High \\
\hline Heat losses & Too High & Medium & No heat loss \\
\hline Technological Level & In Industrial Use & $\begin{array}{l}\text { Preliminary work is } \\
\text { still in progress }\end{array}$ & $\begin{array}{l}\text { Only with some demonstra- } \\
\text { tions }\end{array}$ \\
\hline Storage time & Couple of hours & Couple of hours & More than a month \\
\hline $\begin{array}{c}\text { Temperature of heat } \\
\text { storage }\end{array}$ & A temperature range & $\begin{array}{l}\text { Temperature of } \\
\text { phase transition }\end{array}$ & Ambient temperatures \\
\hline
\end{tabular}

\section{MECHANICAL STORAGE MATERIALS}

Considering the cost, environmental footprint, and sustainability, mechanical energy storage systems are much better than others and attract great attention. Mechanical energy storage can be normally divided into flywheel energy storage (FES), pumped hydropower storage (PHS) and compressed-air energy storage (CAES) [46-48].

\subsection{Flywheel Energy Storage System (FESS)}

In a flywheel energy storage (FESS) system [49] a rotating mass stores energy as kinetic energy for a short-term [50] as shown in Equation (4). They are one of the most effective, fast response storage systems in terms of economic aspects [51].

Flywheels are available in various shapes; laval disc, thick ring, solid disc, and thin ring [52]. Each flywheel features a shape factor $(\mathrm{K})$ reflecting material utilization. Equation (5) represents the specific energy per unit mass which is proportional to $\mathrm{K}$. These equations help to calculate the effect of speed, shape, and inertia on the energy stored by the flywheel [53].

$$
\begin{aligned}
& E=\frac{1}{2} I W^{2} \\
& \frac{E}{m}=K \sigma \text { max } / \rho
\end{aligned}
$$


Where E represents the energy stored, $\mathrm{W}$ is the rotational speed, I is the moment of inertia, $m$ is the mass, $\rho$ is the density of the flywheel, and omax is the maximum stress.

As shown in Figure 3, rotating weight, frequency inverter, and motor-generator are the main parts of the FESS. The design of each component affects the overall efficiency, and one of the main targets is to reduce losses due to power transmission that are determined by the kind of bearing; magnetic bearings proved to be the best selection [54]. In addition to the energy storage, it also increases the battery life [55] in conjunction with renewable sources due to intermittent character.

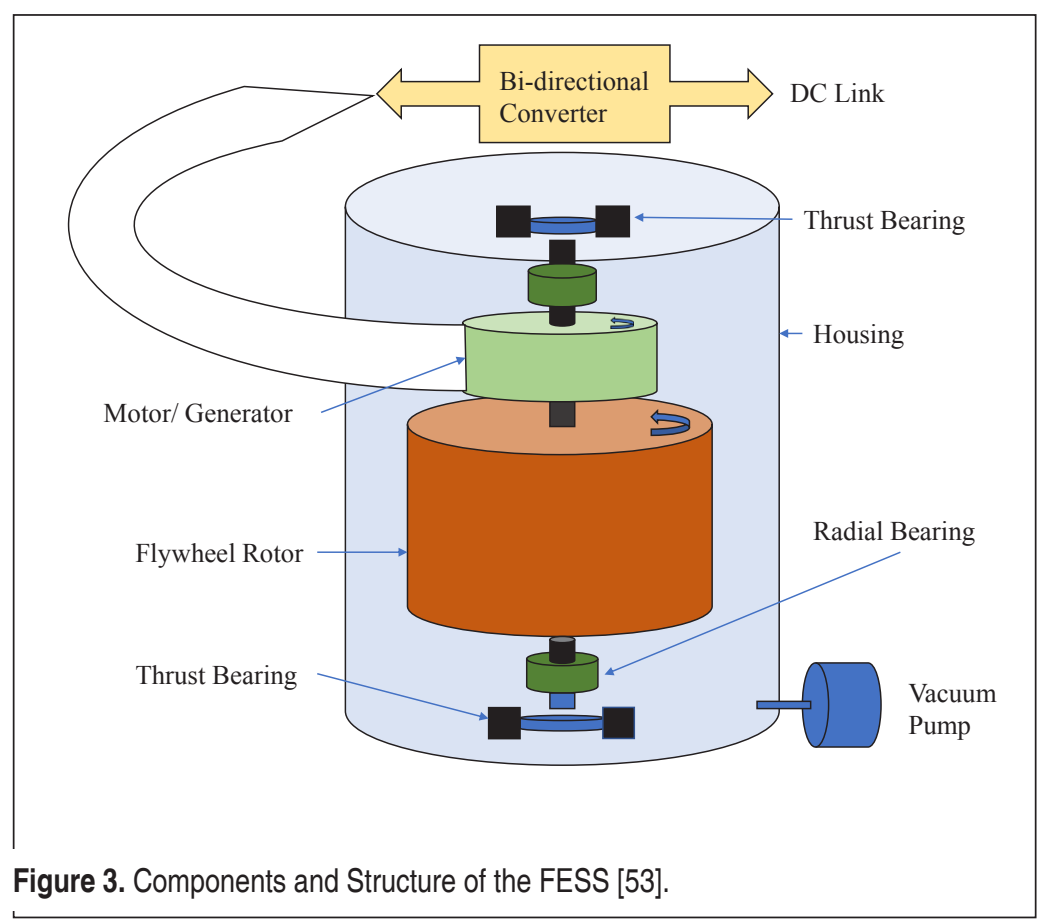

\subsection{Pumped Hydro Energy Storage (PHESS)}

Another type of mechanical energy storage is the pumped hydro energy storage having features such as flexibility, long-life cycle, and low maintenance cost. It is composed of a pumping system, upper reservoir, and hydro turbine [56]. The excess energy containing water is pumped to the upper reservoir and used when needed.

Photo-voltaic power fluctuations can be avoided by solar-PHESS. The Figure 4 shows the working mechanism of the system in day and night. During the day, the heated 
water is pumped to the upper reservoir as storage of energy using the motor, while the same heated water passes to the lower reservoir rotating the turbine to generate the power for use at night [57]. The optimized PHESS reduces the operating costs and is employed in remote areas having no grid supply [58].

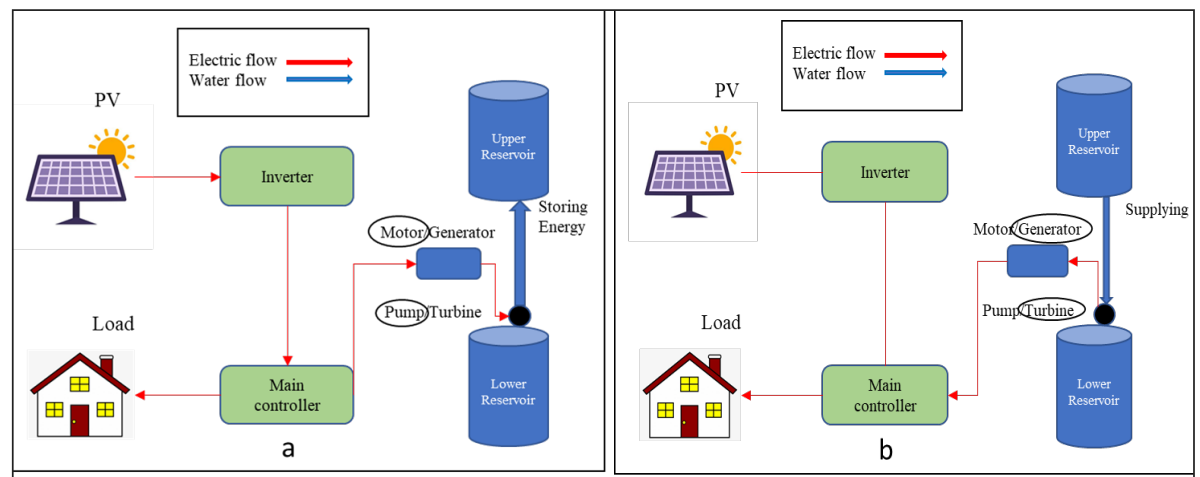

Figure 4. Solar Energy Connected with PHESS (a) Storage; (b) Power Supply [53].

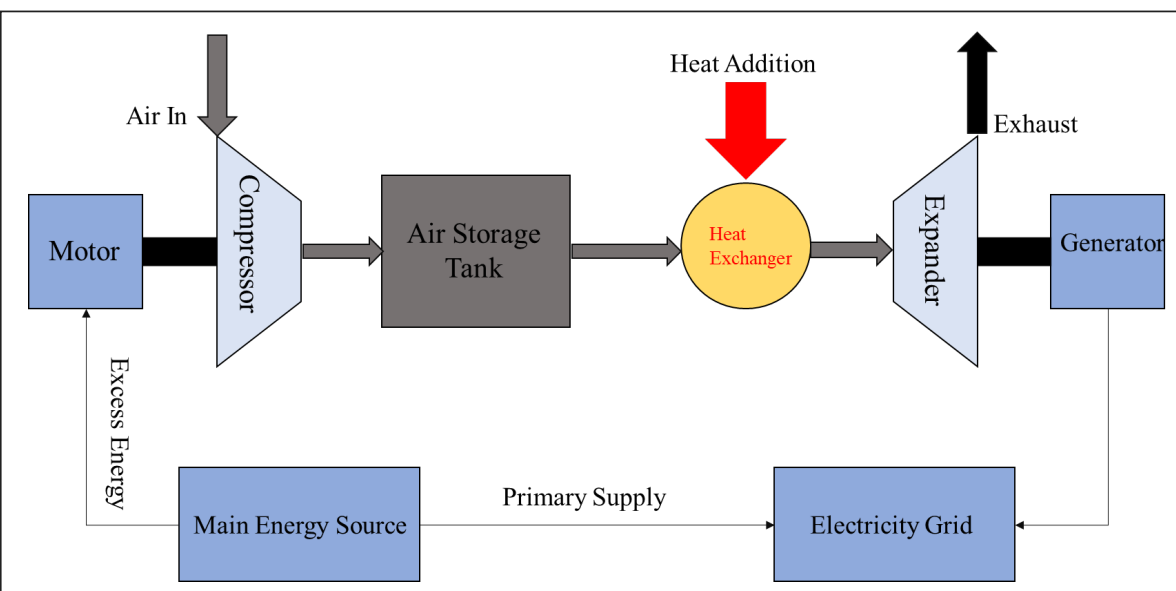

Figure 5. Schematic Diagram of a Conventional CAES [53].

\section{ELECTROMAGNETIC ENERGY STORAGE}

In 1970, superconductive magnetic energy storage, consisting of a liquid nitrogen cooling system and a superconducting coil, was first introduced. In this method, the coil is charged and discharged for energy storage and consumption. The energy storage efficiency of SMES is $>97 \%$ and is prompt. The solar and wind power stabilization, improvement in the quality of electrical power supply, voltage stability, and improvement in the power of industrial sectors are all the benefits of this system. The major 
drawback of SMES as compared to other systems is the high cost of the superconductors, and maintenance cost of cryogenic temperatures. High temperature superconducting materials are expected to lower the cost of a SMES system [60].

\section{ELECTROCHEMICAL ENERGY STORAGE}

Batteries and capacitors are the main sources of electrochemical energy storage. A battery stores electrical energy as chemical energy while a capacitor stores energy as surface charge. Another hybrid form is the supercapacitor exhibiting both the characteristics of batteries and capacitors. Lead-acid, nickel-cadmium, zinc-air, sodiumsulphur, and Li-ion batteries are all the battery types based on the component of the electrodes [61].

Electrochemical energy storage is highly efficient, versatile, and flexible as compared to other energy storage technologies. Among the various rechargeable battery types, Lithium-ion batteries (LIBs) are the most widely utilized as they provide high voltage, long cycling life, high reliability, low toxicity, and low self-discharge.

The LIB was commercialized during the early 1990s and since then has gained worldwide acceptance. It consists of a positive cathode, a negative anode, an electrolyte, and a separator. Mainly lithium cobalt oxide or lithium manganese oxide are cathode materials. The anode materials are carbon, iron oxides, cobalt oxides, $\mathrm{Si}, \mathrm{Sn}$, and nickel oxides [60].

\section{FUTURE OF THE STORAGE MATERIALS}

\subsection{Mechanical Energy Storage}

The energy density of a FES system is linearly dependent on the square of the angular velocity of the flywheel and its mass. Since the material of the flywheel determines the energy density, the faster the rotating speed, the higher the energy density. In this regard, Carbon-fiber reinforced composites having a high strength can serve the purpose. Moreover, carbon nanotubes could prove to be a promising candidate since they have very high tensile strength and young's modulus [62-64].

\subsection{Electrochemical Energy Storage}

Among all the battery systems LIBs have gained popularity over the last thirty years. If pure lithium could be used as an anode or if pure chalcogen could be used as the cathode, the volumetric storage capacity could be enhanced to a considerable extent. Likewise, the energy density could be doubled if the lithium-air cell becomes operable. Apart from the lithium, sodium or magnesium-based batteries could also be considered but the sodium has safety concerns. Sodium reversibly intercalates into 
the chevrel phases, MxMo6S8; it gives a range of phases by intercalating into the chalcogenides and layered oxides [61, 65].

\subsubsection{Iodine-Based Solar Batteries}

The first triiodide/iodide ( $\left.\mathrm{I}_{3}-/ \mathrm{I}-\right)$ redox based solar battery was prepared by Hauch and Orel et al. in 2002 [66] which was influenced by the iodine-based electrolyte usage in dye-sensitized solar cells $[67,68]$.

However, the insufficient concentration of the $\mathrm{Li}+$ in the electrolyte restricts the capacity of the battery and the device performed better in low light making it useful for indoor systems. The colour shifts between $\mathrm{WO}_{3}$ and $\mathrm{Li}_{\mathrm{x}} \mathrm{WO}_{3}$ making the possibility of the device as photo-electrochromic system [69].

\subsubsection{Vanadium-Based Solar Batteries}

The fast kinetics of vanadium based redox flow batteries (RFB), aqueous species, and rich redox chemistry makes them the most widely used RFB systems on the commercial scale in terms of the stationary electrical storage facilities [70-73].

The $\mathrm{TiO}_{2}$ photoelectrode was merged with the vanadium RFB solar cell in 2012 proposing the new vanadium-based solar battery. In this system, during the charging process electron-hole pairs are generated when the incident light is absorbed by the $\mathrm{TiO}_{2}$ photoelectrode. During the night, the discharging process occurs in the same way as before where the $\mathrm{V}_{2}+$ is oxidized in the anolyte and the $\mathrm{VO}_{2}+$ is reduced in the catholyte [74].

Although the $\mathrm{TiO}_{2}$ showed an efficiency of $12 \%$ at $350 \mathrm{~nm}$ of incident photon-toelectron conversion in an acidic environment. However, the device could not absorb light in the shorter wavelength of the light spectrum due to the large $(3.2 \mathrm{eV})$ bandwidth $[75,76]$.

\subsubsection{Selenium and Bromine-Based Solar Batteries.}

For solar batteries, n-MoSe $2 \mid \mathrm{Br}_{2} \mathrm{Br}$ - and n-GasAs $\mid \mathrm{Se}_{2}{ }_{2}-/ \mathrm{Se}^{2}$ - were researched as PEcatholyte combinations in solar batteries. The device with these material combinations achieved a current of around $20 \mathrm{~mA} / \mathrm{cm}^{2}$ and a Voc of $400-500 \mathrm{mV}$ which was much higher than the similar $\mathrm{CdSe} \mid \mathrm{S} / \mathrm{S}^{2}$ - combination. It was believed that the design with flowing electrolyte instead of the static one may help achieve better performance of the device [77].

\subsubsection{The Iodine-Based Lithium-Oxygen Solar Batteries}

A new concept of integration of $\mathrm{TiO}_{2}$ photoelectrode with air electrode using I3-/I- redox couple was applied to the normal $\mathrm{Li}^{-} \mathrm{O}_{2}$ battery in 2014 [78]. The absorbed solar energy reduces the charging potential of the battery by pumping the electrons to the 
higher energy level. The device was photocharged to a much lower value of external voltage $(2.8 \mathrm{~V})$ than the normal lithium-oxygen battery. The dye-sensitized $\mathrm{TiO}_{2}$ photoelectrode is recently replaced by $\mathrm{g}-\mathrm{C}_{3} \mathrm{~N}_{4}$ photocatalyst [79]. However, the major drawback of such system was the inability to be fully charged and a need of a power input for the charging [80].

\subsection{Thermal Energy Storage (PCMS)}

The recently developed phase change materials could be the potential future storage materials which are represented below in Table 2. The $\mathrm{NaNO}_{3}: \mathrm{KNO}_{3}$ mixture has the highest heat capacity per Kg.K while the latent heat is the highest in Al-Si eutectic.

Table 2. Summary of New PCM Material Properties

\begin{tabular}{|c|c|c|c|c|c|c|}
\hline Material & $\begin{array}{c}\text { Heat } \\
\text { Capacity } \\
\text { (KJ/Kg.K) }\end{array}$ & $\begin{array}{c}\text { Latent } \\
\text { Heat (kJ/ } \\
\text { Kg.K) }\end{array}$ & $\begin{array}{l}\text { Volumetric } \\
\text { Energy } \\
\text { Density } \\
\left(\mathrm{MJ} / \mathrm{m}^{3}\right)\end{array}$ & $\begin{array}{c}\text { Operating } \\
\text { Tempera- } \\
\text { tures Melting }\end{array}$ & $\begin{array}{l}\text { Operating } \\
\text { Tempera- } \\
\text { tures So- } \\
\text { lidification }\end{array}$ & $\begin{array}{c}\text { Thermal } \\
\text { Efficiency } \\
(\%)\end{array}$ \\
\hline $\begin{array}{l}\mathrm{NaNO}_{3}: \mathrm{K}- \\
\mathrm{NO}_{3}=60: 40 \text { (molar } \\
\text { ratios) with } 1 \% \\
\mathrm{CuO}[81]\end{array}$ & $1.68-1.93$ & $\begin{array}{l}122.5- \\
178.87\end{array}$ & NA & $\begin{array}{c}216- \\
218.21^{\circ} \mathrm{C}\end{array}$ & NA & NA \\
\hline $\begin{array}{l}\mathrm{NaNO}: \mathrm{K}- \\
\mathrm{NO}_{3}=60: 40 \text { (molar } \\
\text { ratios) [81] }\end{array}$ & $1.24-1.5$ & 107.03 & NA & $219^{\circ} \mathrm{C}$ & NA & NA \\
\hline $\begin{array}{l}\text { Aluminium-silicon } \\
\text { eutectic [82] }\end{array}$ & $1.04-1.74$ & 470 & NA & $577^{\circ} \mathrm{C}$ & NA & NA \\
\hline $\begin{array}{l}\text { Ternary } \\
\text { carbonates [83] }\end{array}$ & $1.22-1.34$ & 247 & NA & $405^{\circ} \mathrm{C}$ & $387^{\circ} \mathrm{C}$ & NA \\
\hline
\end{tabular}

\subsection{Thermochemical Energy Storage}

Table 3 below compares some of the newly developed thermo-chemical energy storage materials. Among all these, the $\mathrm{CaO} / \mathrm{SiO}_{2}$ composite has the highest thermal efficiency of $95.7 \%$. 
Table 3. Summary of New Thermo-Chemical Energy Storage Materials

\begin{tabular}{|c|c|c|c|c|c|}
\hline Reactants & $\begin{array}{c}\text { Operational } \\
\text { Suitability }\end{array}$ & $\begin{array}{c}\text { Energy } \\
\text { Density } \\
\left(\mathrm{MJ} / \mathrm{m}^{3}\right)\end{array}$ & $\begin{array}{c}\text { Operating } \\
\mathrm{T}\left({ }^{\circ} \mathrm{C}\right) \\
\mathrm{Charging}\end{array}$ & $\begin{array}{c}\text { Operating } \mathrm{T}\left({ }^{\circ} \mathrm{C}\right) \\
\text { Discharging }\end{array}$ & $\begin{array}{c}\text { Thermal } \\
\text { Efficiency } \\
(\%)\end{array}$ \\
\hline $\begin{array}{c}\text { Hydroxide looping with } \\
\mathrm{Sr}(\mathrm{OH})_{2} / \mathrm{SrO}[84]\end{array}$ & $\begin{array}{c}\text { Rankine cycle } \\
\text { with subcritical } \\
\text { steam }\end{array}$ & 97.09 & 600 & 525 & 7.09 \\
\hline $\begin{array}{c}\mathrm{Hydroxide} \mathrm{looping} \\
\text { with } \mathrm{Ca}(\mathrm{OH})_{2} / \mathrm{CaO}[84]\end{array}$ & $\begin{array}{c}\text { Rankine cycle } \\
\text { with subcritical } \\
\text { steam }\end{array}$ & 101.97 & 700 & 505 & 4.78 \\
\hline $\begin{array}{c}\mathrm{Redox} \text { with } \mathrm{BaO} / \mathrm{BaO} \\
{[84]}\end{array}$ & $\begin{array}{c}\text { supercritical } \\
\text { cO }{ }_{2} \text { cycle } \\
\text { combined }\end{array}$ & 46.09 & 980 & 690 & 23.93 \\
\hline $\begin{array}{c}\mathrm{CaO} / \mathrm{SiO}_{2} \text { composites } \\
{[85,86]}\end{array}$ & $\mathrm{NA}$ & $\mathrm{NA}$ & 950 & 650 & 95.7 \\
\hline
\end{tabular}

\section{CONCLUSION}

Solar energy has the capacity to fulfil the global demand of energy but the major limitation to accomplishing this potential is inherent intermittency. To get around the problem, many newly developed materials for all the storage systems are being researched and tested. Although thermal energy storage is commercially available, electrochemical storage systems like batteries also seem to be a promising choice for continuous flow of power generation and moving peak sunlight hours of solar energy to peak utilization hours in the near future. Moreover, the newly developed materials for the electrochemical batteries in the solar cells, as discussed in the article, although still in the experimental phase, also seem to offer a better storage capacity. All in all, it can be concluded that the development of new materials will boost the stability and performance of energy storage systems.

\section{Acknowledgements}

The authors would like to thank the Scientific Research Projects Unit of Erciyes University for funding and supporting the project under the contract numbers: FKB-20199134 and FBA-2018-8320

\section{KAYNAKÇA}

1. Mofijur, M., Masjuki, H. H., Kalam, M., Atabani, A. E., Fattah, I. R., Mobarak, H. 2014. "Comparative evaluation of performance and emission characteristics of Moringa oleifera and Palm oil based biodiesel in a diesel engine". Industrial crops and products, vol. 53 , p. $78-84$. 
2. Mofijur, M., Masjuki, H., Kalam, M., Hazrat, M., Liaquat, A., Shahabuddin, M., Varman, M. 2012. "Prospects of biodiesel from Jatropha in Malaysia". Renewable and Sustainable Energy Reviews, vol. 16, p. 5007-5020.

3. Mofijur, M., Masjuki, H., Kalam, M., Atabani, A. 2013. "Evaluation of biodiesel blending, engine performance and emissions characteristics of Jatropha curcas methyl ester: Malaysian perspective". Energy, vol. 55, p. 879-887.

4. Neagu, O., Teodoru, M. C. 2019. "The relationship between economic complexity, energy consumption structure and greenhouse gas emission: Heterogeneous panel evidence from the EU countries". Sustainability, vol. 11, p. 497.

5. Goh, B. H. H., Ong, H. C., Cheah, M. Y., Chen, W.-H., Yu, K. L., Mahlia, T. M. I. 2019. "Sustainability of direct biodiesel synthesis from microalgae biomass: A critical review". Renewable and Sustainable Energy Reviews, vol. 107, p. 59-74.

6. Prasad, D. R., Senthilkumar, R., Lakshmanarao, G., Krishnan, S., Prasad, B. N. 2019. "A critical review on thermal energy storage materials and systems for solar applications". AIMS Energy, vol. 7, p. 507.

7. Martinopoulos, G. 2018. "Life Cycle Assessment of solar energy conversion systems in energetic retrofitted buildings". Journal of Building Engineering, vol. 20, p. 256-263.

8. H Abedin, A., A Rosen, M. 2011. "A critical review of thermochemical energy storage systems". The open renewable energy journal, vol. 4, p.

9. Dharma, S., Masjuki, H., Ong, H. C., Sebayang, A., Silitonga, A., Kusumo, F., Mahlia, T. 2016. "Optimization of biodiesel production process for mixed Jatropha curcasCeiba pentandra biodiesel using response surface methodology". Energy Conversion and Management, vol. 115, p. 178-190.

10. Silitonga, A., Atabani, A., Mahlia, T., Masjuki, H., Badruddin, I. A., Mekhilef, S. 2011. "A review on prospect of Jatropha curcas for biodiesel in Indonesia". Renewable and Sustainable Energy Reviews, vol. 15, p. 3733-3756.

11. Ong, H. C., Masjuki, H., Mahlia, T., Silitonga, A., Chong, W., Leong, K. 2014. "Optimization of biodiesel production and engine performance from high free fatty acid Calophyllum inophyllum oil in CI diesel engine”. Energy Conversion and Management, vol. 81 , p. $30-40$.

12. Xu, B., Li, P., Chan, C. 2015. "Application of phase change materials for thermal energy storage in concentrated solar thermal power plants: a review to recent developments". Applied Energy, vol. 160, p. 286-307.

13. Shivashankar, S., Mekhilef, S., Mokhlis, H., Karimi, M. 2016. "Mitigating methods of power fluctuation of photovoltaic (PV) sources-A review". Renewable and Sustainable Energy Reviews, vol. 59, p. 1170-1184.

14. DeWinter, F. 1990. "Solar collectors, energy storage, and materials", MIT press,

15. Silitonga, A. S., Masjuki, H. H., Ong, H. C., Sebayang, A. H., Dharma, S., Kusumo, F., Siswantoro, J., Milano, J., Daud, K., Mahlia, T. M. I. 2018. "Evaluation of the engine performance and exhaust emissions of biodiesel-bioethanol-diesel blends using kernel-based extreme learning machine". Energy, vol. 159, p. 1075-1087. 
16. Martinopoulos, G., Tsalikis, G. 2018. "Diffusion and adoption of solar energy conversion systems-The case of Greece". Energy, vol. 144, p. 800-807.

17. Barlev, D., Vidu, R., Stroeve, P. 2011. "Innovation in concentrated solar power". Solar energy materials and solar cells, vol. 95, p. 2703-2725.

18. Powell, K.M. and T.F. Edgar, 2011, "Control of a large scale solar thermal energy storage system", in Proceedings of the 2011 American control conference, IEEE.

19. Zhao, C., Wu, Z. 2011. "Thermal property characterization of a low melting-temperature ternary nitrate salt mixture for thermal energy storage systems". Solar Energy Materials and Solar Cells, vol. 95, p. 3341-3346.

20. Cabeza, L. F. 2014. "Advances in thermal energy storage systems: Methods and applications", Elsevier,

21. Gil, A., Medrano, M., Martorell, I., Lázaro, A., Dolado, P., Zalba, B., Cabeza, L. F. 2010. "State of the art on high temperature thermal energy storage for power generation. Part 1 -Concepts, materials and modellization". Renewable and Sustainable Energy Reviews, vol. 14, p. 31-55.

22. Hasnain, S. 1998. "Review on sustainable thermal energy storage technologies, Part I: heat storage materials and techniques". Energy conversion and management, vol. 39, p. $1127-1138$.

23. Kousksou, T., Bruel, P., Jamil, A., El Rhafiki, T., Zeraouli, Y. 2014. "Energy storage: Applications and challenges”. Solar Energy Materials and Solar Cells, vol. 120, p. 59-80.

24. Badran, A. A., Jubran, B. A. 2001. "Fuel oil heating by a trickle solar collector". Energy conversion and management, vol. 42, p. 1637-1645.

25. Marchã, J., Osório, T., Pereira, M. C., Horta, P. 2014. "Development and test results of a calorimetric technique for solar thermal testing loops, enabling mass flow and $\mathrm{Cp}$ measurements independent from fluid properties of the HTF used". Energy Procedia, vol. 49, p. 2125-2134.

26. Liu, M., Saman, W., Bruno, F. 2012. "Review on storage materials and thermal performance enhancement techniques for high temperature phase change thermal storage systems". Renewable and Sustainable Energy Reviews, vol. 16, p. 2118-2132.

27. Wang, T., Mantha, D., Reddy, R. G. 2013. "Novel low melting point quaternary eutectic system for solar thermal energy storage". Applied energy, vol. 102, p. 1422-1429.

28. Cárdenas, B., León, N. 2013. "High temperature latent heat thermal energy storage: Phase change materials, design considerations and performance enhancement techniques". Renewable and sustainable energy reviews, vol. 27, p. 724-737.

29. Hänchen, M., Brückner, S., Steinfeld, A. 2011. "High-temperature thermal storage using a packed bed of rocks-heat transfer analysis and experimental validation". Applied Thermal Engineering, vol. 31, p. 1798-1806.

30. Martins, M., Villalobos, U., Delclos, T., Armstrong, P., Bergan, P. G., Calvet, N. 2015. "New concentrating solar power facility for testing high temperature concrete thermal energy storage”. Energy Procedia, vol. 75, p. 2144-2149. 
31. Schlipf, D., Schicktanz, P., Maier, H., Schneider, G. 2015. "Using sand and other small grained materials as heat storage medium in a packed bed HTTESS". Energy Procedia, vol. 69 , p. 1029-1038.

32. Farid, M. M., Khudhair, A. M., Razack, S. A. K., Al-Hallaj, S. 2004. "A review on phase change energy storage: materials and applications". Energy conversion and management, vol. 45, p. 1597-1615.

33. Pardo, P., Deydier, A., Anxionnaz-Minvielle, Z., Rougé, S., Cabassud, M., Cognet, P. 2014. "A review on high temperature thermochemical heat energy storage". Renewable and Sustainable Energy Reviews, vol. 32, p. 591-610.

34. Silakhori, M., Jafarian, M., Arjomandi, M., Nathan, G. J. 2017. "Comparing the thermodynamic potential of alternative liquid metal oxides for the storage of solar thermal energy". Solar Energy, vol. 157, p. 251-258.

35. Abhat, A. 1983. "Low temperature latent heat thermal energy storage: heat storage materials". Solar energy, vol. 30, p. 313-332.

36. Fallahi, A., Guldentops, G., Tao, M., Granados-Focil, S., Van Dessel, S. 2017. "Review on solid-solid phase change materials for thermal energy storage: Molecular structure and thermal properties". Applied Thermal Engineering, vol. 127, p. 1427-1441.

37. Sharma, R., Ganesan, P., Tyagi, V., Metselaar, H., Sandaran, S. 2015. "Developments in organic solid-liquid phase change materials and their applications in thermal energy storage". Energy Conversion and Management, vol. 95, p. 193-228.

38. Pielichowska, K., Pielichowski, K. 2014. "Phase change materials for thermal energy storage". Progress in materials science, vol. 65, p. 67-123.

39. Buschle, J., W.-D. Steinmann, and R. Tamme, 2006, "Latent heat storage for process heat applications", in Proceedings of the 10th International Conference on Thermal Energy Storage ECOSTOCK, Atlantic City, NJ, USA

40. Li, Y., Wang, J., Tang, J., Liu, Y., He, Y. 2009. "Conductive performances of solid polymer electrolyte films based on $\mathrm{PVB} / \mathrm{LiClO} 4$ plasticized by PEG200, PEG400 and PEG600". Journal of Power Sources, vol. 187, p. 305-311.

41. Sarier, N., Onder, E. 2012. "Organic phase change materials and their textile applications: an overview". Thermochimica Acta, vol. 540, p. 7-60.

42. N'Tsoukpoe, K. E., Schmidt, T., Rammelberg, H. U., Watts, B. A., Ruck, W. K. 2014. "A systematic multi-step screening of numerous salt hydrates for low temperature thermochemical energy storage". Applied Energy, vol. 124, p. 1-16.

43. González-Roubaud, E., Pérez-Osorio, D., Prieto, C. 2017. "Review of commercial thermal energy storage in concentrated solar power plants: Steam vs. molten salts". Renewable and sustainable energy reviews, vol. 80, p. 133-148.

44. Janz, G. J., Allen, C. B., Bansal, N., Murphy, R., Tomkins, R. 1979, "Physical properties data compilations relevant to energy storage. II. Molten salts: data on single and multi-component salt systems", National Standard Reference Data System,

45. Alnaimat, F., Rashid, Y. 2019. "Thermal Energy Storage in Solar Power Plants: A Re- 
view of the Materials, Associated Limitations, and Proposed Solutions". Energies, vol. 12, p. 4164.

46. Lund, H., Salgi, G. 2009. "The role of compressed air energy storage (CAES) in future sustainable energy systems”. Energy conversion and management, vol. 50, p. 1172-1179.

47. Liu, H., Jiang, J. 2007. "Flywheel energy storage-An upswing technology for energy sustainability". Energy and buildings, vol. 39, p. 599-604.

48. Krajačić, G., Lončar, D., Duić, N., Zeljko, M., Arántegui, R. L., Loisel, R., Raguzin, I. 2013. "Analysis of financial mechanisms in support to new pumped hydropower storage projects in Croatia". Applied energy, vol. 101, p. 161-171.

49. Amiryar, M. E., Pullen, K. R. 2017. "A review of flywheel energy storage system technologies and their applications". Applied Sciences, vol. 7, p. 286.

50. Wicki, S., Hansen, E. G. 2017. "Clean energy storage technology in the making: An innovation systems perspective on flywheel energy storage". Journal of cleaner production, vol. 162, p. 1118-1134.

51. Cheng, H., Chen, C., Wu, S., Mirza, Z. A., Liu, Z. 2017. "Emergy evaluation of cropping, poultry rearing, and fish raising systems in the drawdown zone of Three Gorges Reservoir of China". Journal of Cleaner Production, vol. 144, p. 559-571.

52. Sebastián, R., Alzola, R. P. 2012. "Flywheel energy storage systems: Review and simulation for an isolated wind power system". Renewable and Sustainable Energy Reviews, vol. 16, p. 6803-6813.

53. Mahmoud, M., Ramadan, M., Olabi, A.-G., Pullen, K., Naher, S. 2020. "A review of mechanical energy storage systems combined with wind and solar applications". Energy Conversion and Management, vol. 210, p. 112670.

54. Martin, J. E., Rohwer, L. E., Stupak Jr, J. 2016. "Elastic magnetic composites for energy storage flywheels". Composites Part B: Engineering, vol. 97, p. 141-149.

55. Shen, P., Braham, W., Yi, Y., Eaton, E. 2019. "Rapid multi-objective optimization with multi-year future weather condition and decision-making support for building retrofit". Energy, vol. 172, p. 892-912.

56. Koko, S. P., Kusakana, K., Vermaak, H. J. 2018. "Optimal power dispatch of a grid-interactive micro-hydrokinetic-pumped hydro storage system". Journal of Energy Storage, vol. 17 , p. 63-72.

57. Kusakana, K. 2018. "Optimal operation scheduling of grid-connected PV with ground pumped hydro storage system for cost reduction in small farming activities". Journal of Energy Storage, vol. 16, p. 133-138.

58. Tan, S. T., Hashim, H., Lim, J. S., Ho, W. S., Lee, C. T., Yan, J. 2014. "Energy and emissions benefits of renewable energy derived from municipal solid waste: Analysis of a low carbon scenario in Malaysia”. Applied Energy, vol. 136, p. 797-804.

59. Cárdenas, B., Hoskin, A., Rouse, J., Garvey, S. D. 2019. "Wire-wound pressure vessels for small scale CAES”. Journal of Energy Storage, vol. 26, p. 100909.

60. Liu, C., Li, F., Ma, L. P., Cheng, H. M. 2010. “Advanced materials for energy storage”. Advanced materials, vol. 22, p. E28-E62. 
61. Whittingham, M. 2011, "Electrochemical energy storage: Batteries and capacitors, in Fundamentals of Materials for Energy and Environmental Sustainability", Cambridge Univ. Press. p. 608-623.

62. Arani, A. K., Karami, H., Gharehpetian, G., Hejazi, M. 2017. "Review of Flywheel Energy Storage Systems structures and applications in power systems and microgrids". Renewable and Sustainable Energy Reviews, vol. 69, p. 9-18.

63. Guezgouz, M., Jurasz, J., Bekkouche, B., Ma, T., Javed, M. S., Kies, A. 2019. “Optimal hybrid pumped hydro-battery storage scheme for off-grid renewable energy systems". Energy Conversion and Management, vol. 199, p. 112046.

64. He, W., Wang, J. 2018. "Optimal selection of air expansion machine in Compressed Air Energy Storage: A review”. Renewable and Sustainable Energy Reviews, vol. 87, p. 7795.

65. Whittingham, M. S. 1978. "Chemistry of intercalation compounds: metal guests in chalcogenide hosts". Progress in Solid State Chemistry, vol. 12, p. 41-99.

66. Hauch, A., Georg, A., Krašovec, U. O., Orel, B. 2002. "Photovoltaically self-charging battery". Journal of the Electrochemical Society, vol. 149, p. A1208.

67. Grätzel, M. 2011, "Photoelectrochemical cells, in Materials For Sustainable Energy: A Collection of Peer-Reviewed Research and Review Articles from Nature Publishing Group”, World Scientific. p. 26-32.

68. O'regan, B., Grätzel, M. 1991. "A low-cost, high-efficiency solar cell based on dye-sensitized colloidal TiO 2 films". nature, vol. 353, p. 737-740.

69. Saito, Y., Uchida, S., Kubo, T., Segawa, H. 2009. "Energy-storable dye-sensitized solar cells with tungsten oxide charge-storage electrode". ECS Transactions, vol. 16, p. 27.

70. Weber, A. Z., Mench, M. M., Meyers, J. P., Ross, P. N., Gostick, J. T., Liu, Q. 2011. "Redox flow batteries: a review". Journal of applied electrochemistry, vol. 41, p. 1137.

71. Wang, W., Luo, Q., Li, B., Wei, X., Li, L., Yang, Z. 2013. "Recent progress in redox flow battery research and development". Advanced Functional Materials, vol. 23, p. 970986.

72. Rychcik, M., Skyllas-Kazacos, M. 1988. "Characteristics of a new all-vanadium redox flow battery". Journal of power sources, vol. 22, p. 59-67.

73. Joerissen, L., Garche, J., Fabjan, C., Tomazic, G. 2004. "Possible use of vanadium redox-flow batteries for energy storage in small grids and stand-alone photovoltaic systems". Journal of power sources, vol. 127, p. 98-104.

74. Wei, Z., Liu, D., Hsu, C., Liu, F. 2014. “All-vanadium redox photoelectrochemical cell: An approach to store solar energy". Electrochemistry Communications, vol. 45, p. 79-82.

75. Wei, Z., Shen, Y., Liu, D., Hsu, C., Sajjad, S. D., Rajeshwar, K., Liu, F. 2016. "Geometry-enhanced ultra-long $\mathrm{TiO} 2$ nanobelts in an all-vanadium photoelectrochemical cell for efficient storage of solar energy". Nano energy, vol. 26, p. 200-207.

76. Liu, D., Zi, W., Sajjad, S. D., Hsu, C., Shen, Y., Wei, M., Liu, F. 2015. "Reversible 
electron storage in an all-vanadium photoelectrochemical storage cell: synergy between vanadium redox and hybrid photocatalyst". Acs Catalysis, vol. 5, p. 2632-2639.

77. Hada, H., Takaoka, K., Saikawa, M., Yonezawa, Y. 1981. "Energy Conversion and Storage in Solid-state Photogalvanic Cells". Bulletin of the Chemical Society of Japan, vol. 54, p. 1640-1644.

78. Yu, M., Ren, X., Ma, L., Wu, Y. 2014. "Integrating a redox-coupled dye-sensitized photoelectrode into a lithium-oxygen battery for photoassisted charging". Nature communications, vol. 5 , p. 5111.

79. Liu, Y., Li, N., Wu, S., Liao, K., Zhu, K., Yi, J., Zhou, H. 2015. "Reducing the charging voltage of a Li-O 2 battery to $1.9 \mathrm{~V}$ by incorporating a photocatalyst". Energy \& Environmental Science, vol. 8, p. 2664-2667.

80. Yu, M., McCulloch, W. D., Beauchamp, D. R., Huang, Z., Ren, X., Wu, Y. 2015. "Aqueous lithium-iodine solar flow battery for the simultaneous conversion and storage of solar energy". Journal of the American Chemical Society, vol. 137, p. 8332-8335.

81. Awad, A., Burns, A., Waleed, M., Al-Yasiri, M., Wen, D. 2018. "Latent and sensible energy storage enhancement of nano-nitrate molten salt”. Solar Energy, vol. 172, p. 191197.

82. Rea, J. E., Oshman, C. J., Singh, A., Alleman, J., Parilla, P. A., Hardin, C. L., Olsen, M. L., Siegel, N. P., Ginley, D. S., Toberer, E. S. 2018. "Experimental demonstration of a dispatchable latent heat storage system with aluminum-silicon as a phase change material”. Applied energy, vol. 230, p. 1218-1229.

83. Zhang, Z., Yuan, Y., Alelyani, S., Cao, X., Phelan, P. E. 2017. "Thermophysical properties enhancement of ternary carbonates with carbon materials for high-temperature thermal energy storage". Solar Energy, vol. 155, p. 661-669.

84. Bayon, A., Bader, R., Jafarian, M., Fedunik-Hofman, L., Sun, Y., Hinkley, J., Miller, S., Lipiński, W. 2018. "Techno-economic assessment of solid-gas thermochemical energy storage systems for solar thermal power applications". Energy, vol. 149, p. 473-484.

85. Benitez-Guerrero, M., Valverde, J. M., Sanchez-Jimenez, P. E., Perejon, A., Perez-Maqueda, L. A. 2018. "Calcium-Looping performance of mechanically modified $\mathrm{Al}_{2} \mathrm{O}_{3}-\mathrm{CaO}$ composites for energy storage and $\mathrm{CO} 2$ capture". Chemical Engineering Journal, vol. 334, p. 2343-2355.

86. Benitez-Guerrero, M., Valverde, J. M., Perejon, A., Sanchez-Jimenez, P. E., Perez-Maqueda, L. A. 2018. "Low-cost Ca-based composites synthesized by biotemplate method for thermochemical energy storage of concentrated solar power". Applied Energy, vol. 210, p. 108-116. 